\title{
KARAKTERISTIK BISKUIT DARI TEPUNG KORO KRATOK (Phaseolus lunatus L.) TERMODIFIKASI DAN MOCAF (MODIFIED CASSAVA FLOUR)
}

\section{Characteristics of Biscuits from Modified Lima Bean (Phaseolus Lunatus L.) Flour and Mocaf (Modified Cassava Flour)}

\author{
Bayu Octavian Prasetya, Nurud Diniyah*, Riska Rian Fauziah \\ Jurusan Teknologi Hasil Pertanian, Fakultas Teknologi Pertanian \\ Universitas Jember \\ Jl. Kalimantan 37, Kampus Tegal Boto Jember 68121 \\ *Penulis Korespondensi, Email : nurud.ftp@unej.ac.id
}

\begin{abstract}
ABSTRAK
Penentuan karakteristik fisikokimia dan organoleptik biskuit terbaik yang disukai panelis adalah tujuan dari penelitian ini. Rancangan acak lengkap (RAL) digunakan dalam penelitian dengan 6 perlakuan yaitu rasio tepung terigu, MOCAF dan tepung koro kratok termodifikasi P0 (kontrol, 100\% terigu); P1 (25\%:30\%:45\%); P2 (25\%:25\%:50\%); P3 (25\%:20\%:55\%); P4 (25\%:15\%:60\%); P5 (25\%:10\%:65\%) dan P6 (25\%:5\%:70\%). Hasil dianalisis menggunakan SPSS versi 19. Hasil penelitian menunjukkan bahwa perlakuan terbaik dari formulasi dengan rasio penambahan tepung terigu, MOCAF dan tepung koro kratok termodifikasi (25\%:25\%:50\%) dengan karakteristik warna (lightness) 60.10; tekstur $573 \mathrm{~g} / 0.5 \mathrm{~mm}$; kadar air 4.59\%; abu 1.19\%; protein 10.31\%; lemak 17.33\%; karbohidrat $66.58 \%$; serat kasar $0.94 \%$; kesukaan warna, aroma, rasa, tekstur dan kenampakan keseluruhan berturut-turut 3.48; 3.68; 3.84; 3.56; 3.68 (agak suka).

Kata kunci : Biskuit, Koro kratok, MOCAF
\end{abstract}

\section{ABSTRACT}

This study was to investigate the best physicochemical and organoleptic characteristics of biscuit. This research used Complete Randomized Design (CRD) with 6 treatments of the ratio wheat flour, MOCAF and modified lima bean flour, PO (control, 100\% of wheat flour); P1 (25\%:30\%:45\%); P2 (25\%:25\%:50\%); P3 (25\%:20\%:55\%); P4 (25\%:15\%:60\%); P5 (25\%:10\%:65\%) and P6 (25\%:5\%:70\%). The results were analyzed using SPSS statistics version 19. The best treatment was formulation of biscuit with ratio of wheat flour, MOCAF and modified lima bean flour 25:25:50 (P2) which has the characteristic 60.10 of lightness; $573 \mathrm{~g} / 0.5 \mathrm{~mm}$ texture; $4.59 \%$ water content; $1.19 \%$ ash content; $10.31 \%$ protein content; $17.33 \%$ fat content; $66.58 \%$ carbohydrate content; fiber $0.94 \%$; score of colour, flavour, taste, texture and whole appearance respectively were 3.48 ; 3.68; 3.84; 3.56; 3.68 (rather liked).

Keywords : Biscuit, Lima bean, MOCAF

\section{PENDAHULUAN}

Indonesia merupakan negara tropis yang tidak dapat ditumbuhi gandum berdasarkan kondisi iklim negara nya. Salah satu alternatif bahan pangan yang layak dikembangkan adalah koro kratok. Koro kratok (Phaseolus lunatus L) merupakan sumber pangan lokal dengan potensi sangat besar menjadi produk pangan yang dapat mensubstitusi terigu khususnya biskuit. Tanaman koro dikonsumsi dalam bentuk biji dan polong, dan digunakan secara luas sebagai pangan tradisional khususnya di negara Asia, termasuk Indonesia (Nciri et al., 2015). Koro kratok kaya akan protein 19.93-21.40\%, karbohidrat 60.55-74.62\%, lemak $0.99-1.21 \%$, kadar abu $3.46-3.61 \%$, dan serat $4.20-5.50 \%$ dari berbagai varietas koro kratok 
hitam, merah, dan putih (Diniyah et al., 2013) dan memiliki nilai stabilitas emulsi 2.89-4.39 jam; daya emulsi $121.76-164.28 \mathrm{~m}^{2} / \mathrm{g}$; daya buih $25-55 \%$; stabilitas buih $5.12-10 \%$; OHC 213.37-255.71\%; WHC 127.88-188.47\% (Diniyah et al., 2015).

Biskuit secara global dikenal sebagai makanan siap saji sejenis camilan panggang (Kiin-Kabari and Giami, 2015), termasuk kategori makanan ringan yang menggunakan tepung komposit dengan hasil yang lebih baik daripada roti karena bentuknya yang siap makan, luas sebaran konsumsinya, memiliki umur simpan yang relatif panjang dan kualitas makanan yang baik sehingga memungkinkan produksi skala besar dan distribusi yang luas (Bala, Gul and Riar, 2015; Noorfarahzihah et al., 2014). Menurut BPS (2015), rata-rata konsumsi kue kering (biskuit atau cookies) di daerah perkotaan dan pedesaan sampai dengan bulan September 2014 mencapai 0.171 ons seminggu. Tepung komposit sebagai bahan baku dalam hal ini dikehendaki karena dapat meningkatkan nilai produk makanan seperti produk bakery khususnya jika dicampur dengan kacang-kacangan (Adeola and Ohizua, 2017). Salah satu bahan yang bisa digunakan pada proses pengadonan biskuit adalah koro kratok. Tepung koro kratok termodifikasi (TKT) yang difermentasi secara spontan dengan perlakuan fermentasi selama 16 jam pada $\mathrm{pH} 5.5$ memiliki sifat fungsional teknis yang baik meliputi water holding capacity (WHC) $173.51 \pm 26.13 \%$, daya buih $28.22 \pm$ $0.40 \mathrm{ml} / \mathrm{g}$ dan daya emulsi $313.50 \pm 1.62 \mathrm{~m}^{2} / \mathrm{g}$ (Nafi' et al., 2015). Pada proses makanan, termasuk penyimpanan dan preparasi, sifat fungsional didefinisikan sebagai sifat khusus dari bahan termasuk fisikokimia yang berpengaruh terhadap protein dalam makanan (Onimawo and Akubor, 2005).

Penggunaan MOCAF (Modified Cassava Flour) juga dapat digunakan sebagai bahan tambahan dalam pembuatan biskuit dan cookies (Diniyah et al., 2019), beras analog (Diniyah et al., 2016), mi (Diniyah et al., 2017). Proses fermentasi pada pembuatan MOCAF terjadi peningkatan viskositas, kemampuan gelasi, dan daya hidrasi (berkaitan dengan kelarutan). Pembentukan asam-asam amino organik hasil dari hidrolisis pati akan menghasilkan cita rasa tertentu sehingga mampu menutupi cita rasa khas singkong (Widya, 2011) dan kadar karbohidrat pada MOCAF lebih besar dari tepung terigu yaitu sebesar 8587\% (Subagio et al., 2008).

Bahan utama pada proses pembuatan biskuit akan mempengaruhi karakteristik fisik, kimia dan sensoris biskuit. Seiring dengan peningkatan nilai gizi, pada umumnya tidak diimbangi dengan peningkatan mutu fisik biskuit (Gayati, 2014). Dengan demikian, penelitian tentang formulasi tepung koro kratok termodifikasi dan MOCAF dengan substitusi tepung terigu terhadap karakteristik biskuit sehingga dapat menghasilkan biskuit dengan karakteristik fisik, kimia dan sensoris yang terbaik perlu dilakukan.

\section{BAHAN DAN METODE}

\section{Bahan}

Bahan untuk pembuatan tepung koro kratok termodifikasi adalah koro kratok yang didapat dari daerah Cerme, Bondowoso, asam sitrat, air, buffer $\mathrm{pH} 4$ dan natrium klorida $(\mathrm{NaCl})$. Bahan utama dalam pembuatan biskuit meliputi tepung koro kratok termodifikasi, MOCAF yang didapatkan dari toko Mr. Te (Jember), tepung terigu, gula halus, telur, margarin, dan baking powder. Bahan kimia yang digunakan meliputi aquades, $\mathrm{H}_{2} \mathrm{SO}_{4}$ pekat, selenium indikator $\mathrm{PP}$, asam borat $4 \%, \mathrm{NaOH} 40 \%$, petroleum benzen, indikator metil merah metil biru, dan $\mathrm{HCl} 0.02 \mathrm{~N}$ Merck.

\section{Alat}

Peralatan yang digunakan yaitu oven dan mixer merk kirin, loyang, neraca analitik ohaus, cetakan cookies, tekstur analyzer (Brookfield CT3), desikator, oven memmert, colour reader ( Minolta CR-10), soxhlet, kjeldahl, tanur, cawan porselin, botol timbang.

\section{Desain Penelitian}

Desain penelitian ini menggunakan Rancangan Acak Lengkap (RAL) dengan 6 perlakuan variasi jumlah penambahan MOCAF dan tepung koro kratok termodifikasi (30: 45; 
25:50; 20: 55; 15: 60; 10: 65; 5: 70) dengan 25\% terigu untuk semua perlakuan sehingga total adonan $100 \%$ dan kontrol (100\% terigu). Tiap perlakuan diulang sebanyak 3 kali. Data dianalisis dengan aplikasi SPSS dengan Analysis of variance test (ANOVA), jika ada perbedaan nyata diuji dengan DMRT (Duncan Multiple Comparison Test) pada taraf kepercayaan 95\%.

\section{Tahap Penelitian}

Pembuatan Tepung Koro Kratok Terfermentasi Spontan (TKT)

Pembuatan tepung koro kratok terfermentasi spontan menggunakan bahan baku koro kratok yang telah melalui proses peretakan terlebih dahulu, kemudian perendaman dalam larutan asam sitrat dengan perbandingan (3:1), pH 5.5 dan waktu fermentasi 16 jam. Tahap selanjutnya pencucian sebanyak 2 kali untuk menghentikan proses fermentasi. Koro kratok direndam dalam larutan $\mathrm{NaCl} 10 \%$ dengan perbandingan (3:1) selama 15 menit untuk menghentikan proses fermentasi, selanjutnya dilakukan pencucian menggunakan air sebanyak dua kali untuk menghilangkan sisa $\mathrm{NaCl}$ dan dilanjutkan proses penirisan. Tahap berikutnya penggilingan koro kratok dan pengeringan menggunakan oven pada suhu $60^{\circ} \mathrm{C}$ selama 24 jam, dilanjutkan penggilingan kedua. Proses terakhir adalah pengayakan dengan ukuran 80 mesh (Nafi' et al., 2015).

\section{Pembuatan Biskuit}

Awal pembuatan biskuit yaitu dengan mencampurkan gula halus dan margarin, diaduk menggunakan mixer (kecepatan tinggi) hingga warna adonan memucat. Proses selanjutnya adalah penambahan telur kemudian diaduk kembali sampai sedikit mengembang. Tahap selanjutnya tepung terigu, MOCAF, tepung koro kratok termodifikasi dan baking powder ditambahkan ke dalam adonan, diaduk (kecepatan rendah) hingga kalis, selanjutnya dilakukan pemipihan dengan tebal $\pm 0.50 \mathrm{~cm}$, kemudian melalui tahap pencetakan. Pemanggangan selama 30 menit, suhu $120^{\circ} \mathrm{C}$ hingga warna biskuit coklat keemasan.

\section{Metode Penelitian}

Tepung koro kratok terfermentasi spontan (TKT) dibuat terlebih dahulu berdasarkan Nafi et al., (2015). Pembuatan biskuit dilanjutkan kemudian dengan mencampurkan berbagai bahan utama dan tambahan. Adapun perlakuan dari penelitian ini yaitu :

P0 = rasio tepung terigu: MOCAF: TKT (100:0:0)

$\mathrm{P} 1$ = rasio tepung terigu: MOCAF: TKT $(25: 30: 45)$

$\mathrm{P} 2$ = rasio tepung terigu: MOCAF: TKT (25:25:50)

P3 = rasio tepung terigu: MOCAF: TKT (25:20:55)

$\mathrm{P} 4$ = rasio tepung terigu: MOCAF: TKT $(25: 15: 60)$

P5 $=$ rasio tepung terigu: MOCAF: TKT (25:10:65)

P6 = rasio tepung terigu: MOCAF: TKT (25:5:70)

Adonan dicetak dan dipanggang (suhu $120^{\circ} \mathrm{C}, 30$ menit). Biskuit kemudian dianalisis sifat fisik (kecerahan dan tekstur), kimia (kadar air, kadar abu, kadar protein, kadar lemak, kadar karbohidrat dan serat kasar), dan uji organoleptik dengan parameter warna, rasa, kerenyahan, dan kenampakan umum.

\section{Prosedur Analisis}

Parameter pengujian penelitian ini meliputi uji fisik (kecerahan, Adeola and Ohizua, 2017 dan tekstur, Uthumporn et al., 2015), kimia (kadar air, kadar abu, kadar protein, kadar lemak, kadar karbohidrat, kadar serat) (AOAC, 2010), organoleptik (warna, aroma, rasa, tekstur dan keseluruhan). Data uji organoleptik diperoleh dari 25 panelis umum didasarkan pada parameter warna, aroma, rasa, kerenyahan dan kenampakan keseluruhan menggunakan 5-poin skala hedonik (Iwe, 2002). Perlakuan terbaik ditentukan berdasarkan hasil analisis uji fisik, kimia dan organoleptik menggunakan uji efektifitas (De Garmo, et al., 1984). 


\section{HASIL DAN PEMBAHASAN}

\section{Sifat Fisik Biskuit}

\section{Kecerahan Warna}

Hasil analisis ragam dengan $\alpha=5 \%$ menggambarkan bahwa biskuit yang dibuat dengan substitusi tepung koro kratok termodifikasi dan MOCAF berpengaruh nyata pada nilai kecerahan biskuit yang dihasilkan. Penggunaan tepung koro kratok termodifikasi semakin banyak maka nilai kecerahan biskuit semakin kecil (gelap). Kandungan protein tepung koro kratok termodifikasi yaitu 33.74\% (Nafi' et al., 2015) lebih tinggi dibandingkan dengan MOCAF yaitu sebesar maksimal 1.00\% (Subagio et al., 2008) serta tepung terigu 14.7\% (Okpala and Egwu, 2015). Reaksi kimia antara asam amino dan gula reduksi dengan proses pemasakan menggunakan suhu tinggi menyebabkan proses pencoklatan atau terbentuk produk reaksi maillard lebih cepat (Tamanna and Mahmood, 2014).

Tabel 1. Nilai Kecerahan dan Tekstur Biskuit Perlakuan Rasio Tepung Terigu, MOCAF, dan Tepung Koro Kratok Termodifikasi

\begin{tabular}{ccc}
\hline Rasio tepung terigu: MOCAF: TKT & Kecerahan & $\begin{array}{c}\text { Tekstur } \\
\mathbf{( g / m m})\end{array}$ \\
\hline P0 $(100: 0: 0)$ & $67.52 \mathrm{e} \pm 0.64$ & $520.37 \mathrm{a} \pm 8.31$ \\
P1 $(25: 30: 45)$ & $61.68 \mathrm{~d} \pm 0.62$ & $561.67 \mathrm{~b} \pm 2.50$ \\
P2 $(25: 25: 50)$ & $60.10 \mathrm{c} \pm 0.96$ & $573.00 \mathrm{~b} \pm 7.29$ \\
P3 $(25: 20: 55)$ & $59.09 \mathrm{c} \pm 0.94$ & $598.53 \mathrm{c} \pm 8.25$ \\
P4 $(25: 15: 60)$ & $57.55 \mathrm{~b} \pm 0.51$ & $622.97 \mathrm{~d} \pm 4.55$ \\
P5 $(25: 10: 65)$ & $56.76 \mathrm{~b} \pm 0.71$ & $629.87 \mathrm{~d} \pm 8.55$ \\
P6 (25:5:70) & $53.61 \mathrm{a} \pm 0.75$ & $770.23 \mathrm{e} \pm 6.35$ \\
\hline
\end{tabular}

Tekstur

Hasil analisis ragam pada $\alpha=5 \%$ memberikan penjelasan bahwa biskuit yang dibuat dengan substitusi tepung koro kratok termodifikasi dan MOCAF berpengaruh nyata pada tekstur biskuit yang dihasilkan. Tabel 1 menunjukkan bahwa penambahan tepung koro kratok termodifikasi yang semakin banyak menyebabkan tekstur biskuit semakin keras (nilai semakin besar). Tekstur biskuit dapat dipengaruhi oleh kandungan serat dari bahan baku yang digunakan. Kandungan serat kasar biskuit semakin meningkat seiring dengan bertambahnya penggunaan tepung koro kratok termodifikasi sehingga tekstur biskuit yang dihasilkan menjadi lebih keras. Serat memiliki permukaan yang luas sehingga kemampuan menyerap airnya lebih tinggi (Darojat, 2010). Serat merupakan polikasarida yang dalam bahan makanan berfungsi sebagai penguat tekstur. Semakin tinggi kadar serat maka akan dihasilkan produk dengan tekstur yang lebih kokoh dan kuat akibatnya produk menjadi lebih keras dan daya patahnya meningkat (Winarno, 1992).

\section{Sifat Kimia Biskuit}

\section{Kadar Air}

Hasil analisis ragam pada $\alpha=5 \%$ menunjukkan bahwa biskuit yang dibuat dengan substitusi tepung koro kratok termodifikasi dan MOCAF tidak berpengaruh nyata terhadap kadar air biskuit yang dihasilkan tetapi kecenderungan nya menunjukkan semakin banyak penambahan tepung koro kratok termodifikasi maka semakin tinggi kadar air biskuit yang dihasilkan. Peningkatan kadar air biskuit dapat dipengaruhi oleh kadar protein terlarut tepung koro kratok termodifikasi lebih tinggi 33.74\% (Nafi' et al., 2015) dibanding dengan MOCAF maksimal 1.00\% (Subagio et al., 2008). Sifat hidrasi merupakan sifat fungsional protein untuk memerangkap air dan menahannya dalam suatu sistem pangan. Rentang nilai rata-rata yang dihasilkan biskuit dari tepung koro kratok termodifikasi dan MOCAF ini berkisar 4.54-4.87\% sedangkan kadar air biskuit berbahan campuran tepung terigu dan jangkrik yaitu 3.25-4.73\% (Dignity et al., 2017); biskuit dengan penambahan bekatul jagung 
berkisar 5.28-8.91\% (Setyowati dan Nisa, 2014), biskuit dari tepung beras dan talas yaitu 6.56-7.89\% (Okpala and Egwu, 2015).

Tabel 2. Sifat Kimia Biskuit dengan Rasio Tepung Terigu, MOCAF, dan Tepung Koro Kratok Termodifikasi

\begin{tabular}{ccccccc}
\hline $\begin{array}{c}\text { Rasio tepung } \\
\text { terigu: MOCAF: } \\
\text { TKT }\end{array}$ & \multicolumn{7}{c}{ Padar Air (\%) } & Protein (\%) & Lemak (\%) & Abu (\%) & Karbohidrat (\%) & Serat (\%) \\
\hline P0 (100:0:0) & $4.54 \mathrm{a} \pm 0.50$ & $8.29 \mathrm{a} \pm 0.38$ & $18.31 \mathrm{a} \pm 0.51$ & $0.91 \mathrm{a} \pm 0.13$ & $67.95 \mathrm{~d} \pm 1.18$ & $0.14 \mathrm{a} \pm 0.11$ \\
P1 (25:30:45) & $4.57 \mathrm{a} \pm 0.11$ & $9.39 \mathrm{~b} \pm 0.62$ & $17.32 \mathrm{a} \pm 0.22$ & $1.18 \mathrm{~b} \pm 0.07$ & $67.54 \mathrm{~d} \pm 0.36$ & $0.89 \mathrm{~b} \pm 0.12$ \\
P2 (25:25:50) & $4.59 \mathrm{a} \pm 0.56$ & $10.31 \mathrm{bc} \pm 0.86$ & $17.33 \mathrm{a} \pm 0.46$ & $1.19 \mathrm{~b} \pm 0.10$ & $66.58 \mathrm{~cd} \pm 0.85$ & $0.94 \mathrm{~b} \pm 0.15$ \\
P3 (25:20:55) & $4.69 \mathrm{a} \pm 0.54$ & $10.94 \mathrm{c} \pm 0.74$ & $17.53 \mathrm{a} \pm 0.47$ & $1.23 \mathrm{bc} \pm 0.13$ & $65.62 \mathrm{bc} \pm 1.60$ & $1.01 \mathrm{~b} \pm 0.11$ \\
P4 (25:15:60) & $4.72 \mathrm{a} \pm 0.47$ & $12.11 \mathrm{~d} \pm 0.40$ & $17.78 \mathrm{a} \pm 0.22$ & $1.41 \mathrm{~cd} \pm 0.13$ & $63.98 \mathrm{ab} \pm 0.48$ & $1.06 \mathrm{~b} \pm 0.30$ \\
P5 (25:10:65) & $4.80 \mathrm{a} \pm 0.68$ & $12.71 \mathrm{de} \pm 0.39$ & $17.79 \mathrm{a} \pm 0.33$ & $1.43 \mathrm{~cd} \pm 0.13$ & $63.26 \mathrm{a} \pm 1.12$ & $1.11 \mathrm{~b} \pm 0.20$ \\
P6 (25:5:70) & $4.87 \pm 0.30$ & $13.33 \mathrm{e} \pm 0.17$ & $18.14 \mathrm{a} \pm 0.46$ & $1.46 \mathrm{~d} \pm 0.04$ & $62.21 \mathrm{a} \pm 0.64$ & $1.17 \mathrm{~b} \pm 0.18$ \\
\hline
\end{tabular}

Kadar Protein

Hasil analisis ragam pada $\alpha=5 \%$ dapat menjelaskan bahwa biskuit yang dibuat dengan substitusi tepung koro kratok termodifikasi dan MOCAF berpengaruh nyata pada kadar protein biskuit. Penambahan tepung koro kratok termodifikasi semakin banyak maka menyebabkan kadar protein biscuit meningkat. Demikian pula sebaliknya, dengan adanya penambahan MOCAF menjadikan kadar protein biscuit menurun. Peningkatan kandungan protein biskuit linier dengan meningkatnya kandungan protein tepung koro kratok termodifikasi yaitu 33.74\% (Nafi' et al., 2015) dibandingkan dengan MOCAF yaitu sebesar maksimal 1.00\% (Subagio et al., 2008) sedangkan tepung terigu 14.7\% (Okpala and Egwu, 2015). Hal tersebut menyebabkan dengan adanya penambahan tepung koro kratok termodifikasi mengakibatkan semakin tinggi kadar protein biskuit yang dihasilkan. Sejalan dengan Ratnasari dan Yunianta (2015), penambahan kacang hijau (kadar protein sebesar $19.09 \%)$ menjadikan kadar protein biskuit meningkat.

Kadar Lemak

Hasil analisis ragam memaparkan bahwa biskuit yang dibuat dengan substitusi tepung koro kratok termodifikasi dan MOCAF tidak berpengaruh nyata pada kadar lemak biskuit. Perbedaan yang tidak signifikan disebabkan oleh kandungan lemak dari tepung koro kratok termodifikasi dan MOCAF yang relatif kecil yaitu 1.88\% (Nafi' et al., 2015) dan 0.40 $0.80 \%$ (Subagio et al., 2008), sehingga variasi penambahan tepung koro kratok termodifikasi dan MOCAF tidak meningkatkan kadar lemak biskuit secara signifikan. Kadar lemak biskuit dari campuran tepung beras dan talas yaitu 11.17-18.52\% (Okpala and Edwu, 2015), campuran tepung pisang, kacang tunggak dan ubi jalar yaitu 16.03-18.84\% (Adeola and Ohizua, 2017).

\section{Kadar Abu}

Hasil analisis ragam menjelaskan bahwa biskuit yang dibuat dengan substitusi tepung koro kratok termodifikasi dan MOCAF berpengaruh nyata terhadap kadar abu biskuit. Beberapa nilai kadar abu biskuit dengan berbagai campuran bahan baku yaitu $2.51-3.31 \%$ (Klunklin and Savage, 2018), 1.07-1.42\% (Dignity et al., 2017). Nilai kadar abu yang dihasilkan dalam penelitian ini lebih rendah yaitu berkisar $0.91-1.46 \%$. Kadar abu tepung koro kratok termodifikasi sebesar $4.70 \%$ (Nafi' et al., 2015), MOCAF maksimal $0.20 \%$ (Subagio et al., 2008) dan tepung terigu berkisar 0.56-1.70\% (Bressiani et al, 2017). Hal tersebut menyebabkan banyaknya penambahan tepung koro kratok termodifikasi menyebabkan kadar abu biskuit semakin tinggi. Sejalan dengan Ratnasari dan Yunianta (2015), penambahan tepung kacang hijau menyebabkan peningkatan kadar abu. 
Kadar Karbohidrat

Hasil analisis ragam memberikan informasi bahwa biskuit yang dibuat dengan substitusi tepung koro kratok termodifikasi dan MOCAF berpengaruh nyata pada kadar karbohidrat biskuit. Penambahan MOCAF yang semakin banyak menjadikan semakin besar kadar karbohidrat biskuit. Demikian pula sebaliknya, penambahan tepung koro kratok termodifikasi menjadikan kadar karbohidrat biskuit menurun. Hal ini dapat disebabkan karena bagian terbesar tepung terigu merupakan karbohidrat yaitu sebesar $78.10 \%$ (Okpala and Egwu, 2015). MOCAF memiliki kandungan pati sebesar $85-87 \%$ (Subagio et al., 2008). Komponen lain seperti protein, lemak, air, dan abu, mempengaruhi penghitungan kadar karbohidrat, jumlah komponen nutrisi lain rendah menyebabkan kadar karbohidrat meningkat (Subandoro et al., 2013).

\section{Kadar Serat Kasar}

Hasil analisis ragam menunjukkan, biskuit yang dibuat dengan penambahan tepung koro kratok termodifikasi dan MOCAF berpengaruh nyata pada kadar serat kasar biskuit. Penambahan tepung koro kratok termodifikasi yang semakin banyak maka serat kasar biskuit juga semakin besar. Hal ini dapat dikarenakan tepung terigu mempunyai kadar serat kasar 12.96-28.59\% (Klunklin and Savage, 2018). Sedangkan untuk kandungan serat biji kering koro berbagai varietas per $100 \mathrm{~g}$ yaitu berkisar 29.32-46.77 g (Kan et al., 2017) dan MOCAF sebesar $1.90-3.40 \%$ (Subagio et al., 2008).

\section{Sifat Organoleptik Biskuit}

\section{Warna}

Penerimaan panelis terhadap warna biskuit cenderung meningkat seiring banyaknya tepung MOCAF yang digunakan pada formulasi pembuatan biskuit. Hasil rata-rata nilai organoleptik warna biskuit berkisar antara $3.20-3.92$. Penilaian panelis terhadap warna biskuit tertinggi yaitu pada formulasi kontrol (100\% tepung terigu) sebesar 3.92 (suka) sedangkan nilai terendah pada formulasi P6 (25\% tepung terigu : 5\% MOCAF : $70 \%$ tepung koro kratok termodifikasi) sebesar 3.20 (agak suka). Hasil organoleptik warna terhadap biskuit dipengaruhi oleh kandungan protein pada tepung koro kratok termodifikasi dan MOCAF. Penambahan tepung koro kratok termodifikasi yang semakin banyak maka cenderung menurunkan penilaian panelis terhadap warna biskuit. Kandungan protein yang tinggi menyebabkan proses pencoklatan lebih cepat karena proses transfer panas udara di dalam oven. Beberapa proses pada makanan dapat menyebabkan reaksi maillard termasuk pemanggangan biskuit juga dapat menghasilkan produk berwarna coklat (permukaan biskuit) sebagai akibat reaksi Maillard (Tamanna and Mahmood, 2014; Wei et al., 2019; Oracz and Nebesny, 2019; Lund and Ray, 2020),

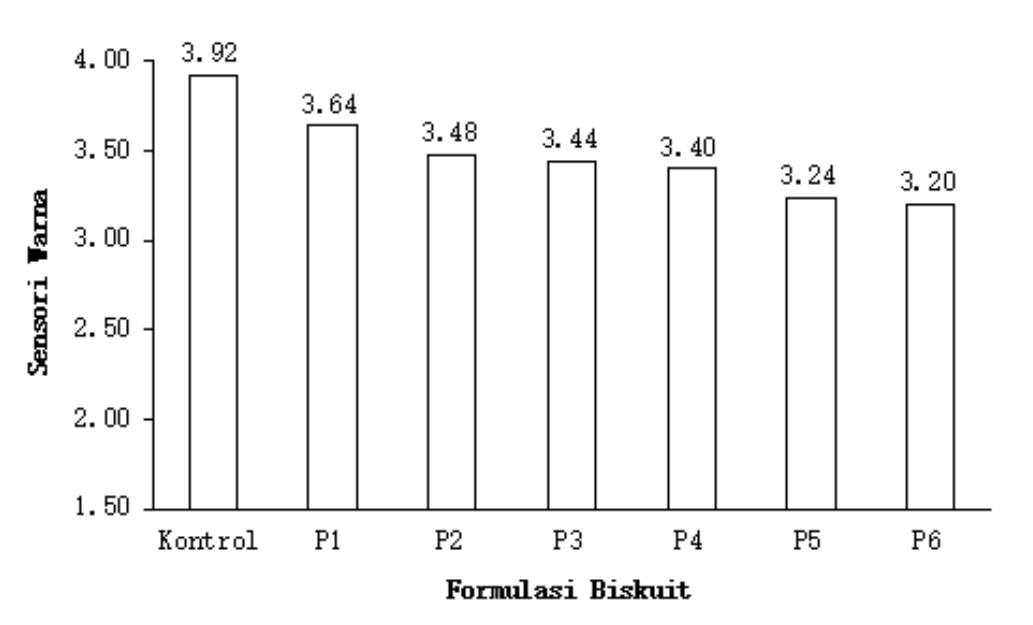

Gambar 1. Tingkat Kesukaan Warna terhadap Biskuit dengan Perlakuan Perbedaan Rasio Terigu, MOCAF, dan Tepung Koro Kratok Termodifikasi 
Aroma

Hasil rata-rata nilai aroma biskuit berkisar antara 2.68 - 3.68. Penilaian panelis terhadap aroma biskuit yang memiliki nilai tertinggi yaitu pada formulasi P2 (25\% tepung terigu : 25\% MOCAF : $50 \%$ tepung koro kratok termodifikasi) sebesar 3.68 (suka) sedangkan nilai terendah pada formulasi P6 (25\% tepung terigu : 5\% MOCAF : $70 \%$ tepung koro kratok termodifikasi) sebesar 2.68 (tidak suka). Semakin tinggi nilai rata-rata aroma biskuit maka semakin disukai oleh panelis.

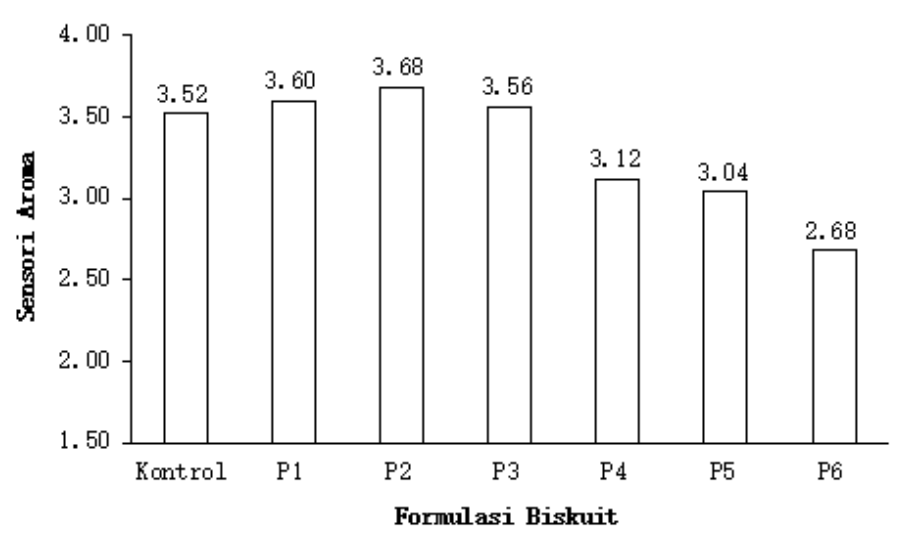

Gambar 2. Tingkat Kesukaan Aroma terhadap Biskuit dengan Perlakuan Perbedaan Rasio Terigu, MOCAF, dan Tepung Koro Kratok Termodifikasi

Hasil nilai aroma terhadap biskuit dipengaruhi oleh adanya penambahan tepung koro kratok termodifikasi dan MOCAF. Penerimaan panelis terhadap aroma biskuit cenderung berfluktuasi. Aroma yang tidak enak diduga disebabkan oleh bau langu dari kacangkacangan yang mengakibatkan produk akhir menjadi kurang diterima panelis. Bau langu timbul akibat adanya enzim lipoksigenase yang mengoksidasi asam lemak pada kacang koro seperti aldehid, alkohol, keton, komponen sulfur, pirazin dan lain-lainnya (Roland et al, 2017).

Rasa

Hasil rata-rata nilai rasa biskuit berkisar antara 2.84 - 3.84. Penilaian panelis terhadap rasa biskuit yang memiliki nilai tertinggi yaitu pada formulasi P2 (25\% tepung terigu : $25 \%$ MOCAF : $50 \%$ tepung koro kratok termodifikasi) sebesar 3.84 (suka) sedangkan nilai terendah pada formulasi P6 (25\% tepung terigu : 5\% MOCAF : 70\% tepung koro kratok termodifikasi) sebesar 2.84 (agak suka). Semakin tinggi nilai rata-rata rasa biskuit maka semakin disukai panelis. Pada beberapa penelitian terdahulu dengan menggunakan tepung campuran berbagai bahan juga menunjukkan adanya tingkat kesukaan dari panelis (Adeola and Ohizua, 2017; Dignity et al., 2018; Klunklin and Savage, 2018)

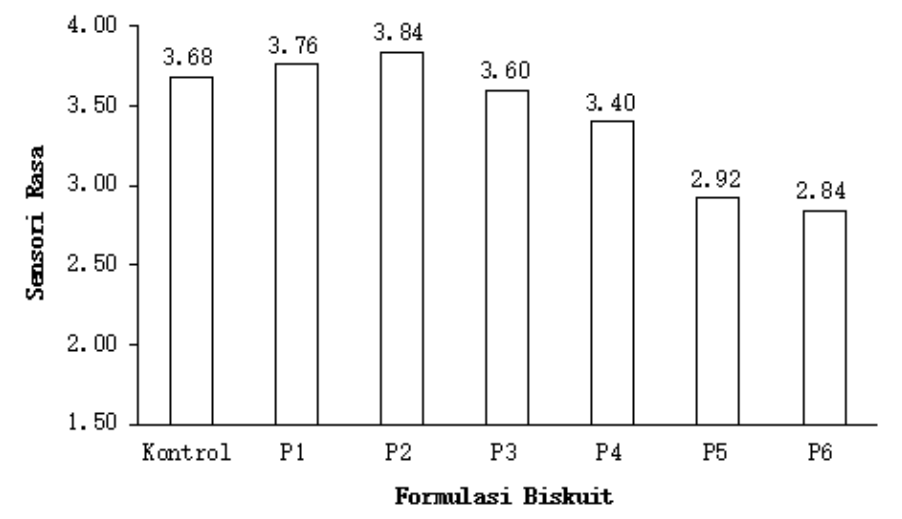

Gambar 3. Tingkat Kesukaan Rasa terhadap Biskuit dengan Perlakuan Perbedaan Rasio Terigu, MOCAF, dan Tepung Koro Kratok Termodifikasi 
Kerenyahan

Hasil rata-rata nilai tekstur biskuit berkisar antara $3.16-3.80$. Penilaian panelis terhadap tekstur biskuit dengan nilai tertinggi yaitu pada formulasi kontrol (100\% tepung terigu) sebesar 3.80 sedangkan nilai terendah pada formulasi P6 (25\% tepung terigu : 5\% MOCAF : 70\% tepung koro kratok termodifikasi) sebesar 3.16 (suka). Semakin tinggi nilai rata-rata tekstur biskuit maka semakin disukai oleh panelis. Penerimaan panelis terhadap tekstur biskuit masih dapat menerima pada rasio tepung terigu, MOCAF dan tepung koro kratok termodifikasi. Pembuatan biskuit berbagai campuran tepung, panelis juga masih dapat menerima pada parameter kerenyahan (Adeola and Ohizua, 2017).

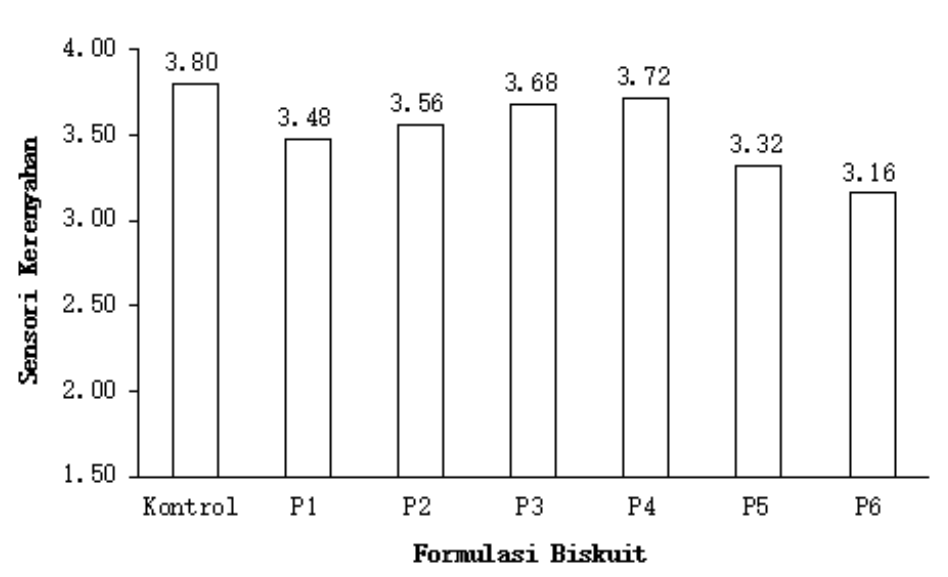

Gambar 4. Tingkat Kesukaan Kerenyahan terhadap Biskuit dengan Perlakuan Perbedaan Rasio Terigu, MOCAF, dan Tepung Koro Kratok Termodifikasi

Keseluruhan

Hasil rata-rata nilai kenampakan keseluruhan biskuit dengan substitusi tepung koro kratok termodifikasi dan MOCAF berkisar antara 3.04 - 3.68. Penilaian panelis terhadap keseluruhan biskuit dengan substitusi tepung koro kratok termodifikasi dan MOCAF memiliki nilai tertinggi yaitu pada formulasi P2 (25\% tepung terigu : 25\% MOCAF : 50\% tepung koro kratok termodifikasi) sebesar 3.68. Semakin tinggi nilai keseluruhan biskuit maka semakin disukai oleh panelis. Pada penelitian sebelumnya terkait penerimaan keseluruhan terhadap biskuit dari berbagai campuran tepung juga menunjukkan masih dapat diterima oleh panelis (Adeola and Ohizua, 2017; Klunklin and Savage, 2018)

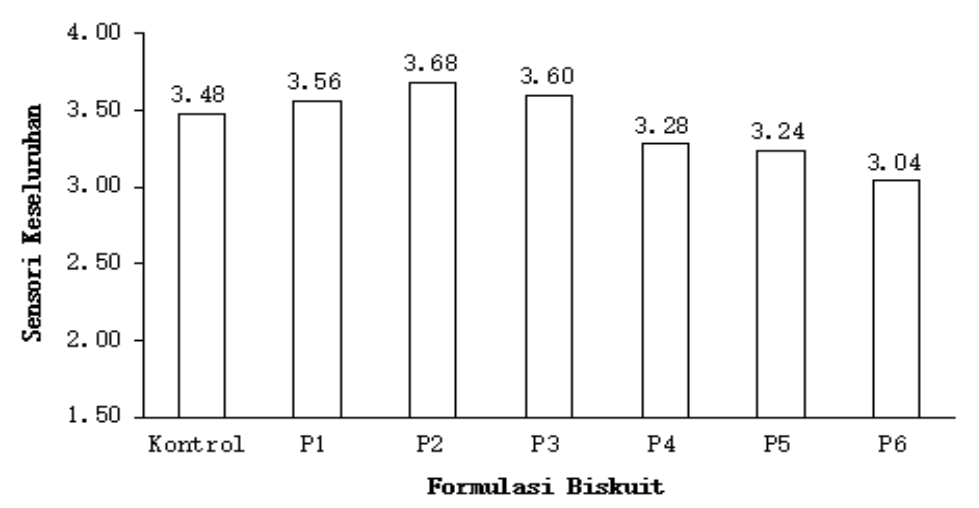

Gambar 5. Tingkat Kesukaan Keseluruhan terhadap Biskuit dengan Perlakuan Perbedaan Rasio Terigu, MOCAF, dan Tepung Koro Kratok Termodifikasi

Nilai kenampakan keseluruhan merupakan kesimpulan penilaian terhadap biskuit dari beberapa parameter yang dilakukan. Menurut Winarno (2007), meskipun berbagai cara analisis obyektif dapat digunakan sebagai tanda adanya penurunan mutu bahan makanan, 
tetapi penentuan akhir adalah kepuasan panelis. Oleh karena itu, pengujian organoleptik sering memegang peranan penting pada akhir penerimaan konsumen terhadap produk.

\section{Uji Efektivitas}

Uji efektifitas merupakan uji untuk mengetahui penentuan perlakuan terbaik berdasarkan beberapa parameter yang telah diuji. Berdasarkan data sifat fisik, kimia dan organoleptik biskuit kemudian dilakukan uji efektifitas untuk memperoleh perlakuan terbaik. Nilai efektifitas ditunjukkan pada Tabel 3.

Tabel 3. Nilai Efektivitas Biskuit

\begin{tabular}{cc}
\hline Perlakuan & Nilai \\
\hline Kontrol & 3.48 \\
P1 & 3.56 \\
P2 & 3.68 \\
P3 & 3.60 \\
P4 & 3.28 \\
P5 & 3.24 \\
P6 & 3.04 \\
\hline
\end{tabular}

Berdasarkan Tabel 3 diketahui bahwa hasil uji efektifitas pada tiap perlakuan berkisar antara 3.04 - 3.68. Nilai tertinggi pada perlakuan P2 dengan rasio penambahan tepung terigu, MOCAF dan tepung koro kratok termodifikasi (25\%:25\%:50\%) sebesar 3.68, sedangkan nilai terendah pada perlakuan P6 (25\%:5\%:70\%) sebesar 3.04 .

\section{SIMPULAN}

Penambahan tepung koro kratok termodifikasi dan MOCAF berpengaruh nyata terhadap karakteristik fisik (warna dan tekstur) dan kimia (kadar abu, kadar protein, kadar karbohidrat, kadar serat kasar) biskuit. Formulasi pembuatan biskuit terbaik dan disukai panelis adalah formulasi P2 dengan menggunakan kombinasi formulasi tepung terigu, MOCAF dan tepung koro kratok termodifikasi P2 (25\%:25\%:50\%) dengan karakteristik biskuit memiliki nilai warna (lightness) 60.10 , tekstur $573 \mathrm{~g} / 0.5 \mathrm{~mm}$, kadar air $4.59 \%$, abu $1.19 \%$, protein $10.31 \%$, lemak $17.33 \%$, karbohidrat $66.58 \%$ dan serat kasar $0.94 \%$. Perlu dilakukan variasi suhu dan lama waktu pengovenan biskuit dengan kombinasi tepung koro kratok termodifikasi dan MOCAF untuk memproduksi biskuit dengan karakteristik fisik (warna dan tekstur) yang baik.

\section{DAFTAR PUSTAKA}

Adeola, A. A., Ohizua, E. R. 2017. Physical, chemical, and sensory properties of biscuits prepared from flour blends of unripe cooking banana, pigeon pea, and sweet potato. Food Science and Nutrition 2018:6, 532-540.

AOAC. 2010. Official Methods of Analysis of The Association of Official Analytical Chemists. Washington DC.

Badan Pusat Statistik. 2015. Pengeluaran Untuk Konsumsi Penduduk Indonesia. Katalog BPS: 3201004. Jakarta.

Bala, A., Gul, K., Riar, C. S. 2015. Functional and sensory properties of cookies prepared from wheat flour supplemented with cassava and water chestnut flours. Cogent Food and Agriculture 1, 1019815.

Bressiani, J., Oro, T., Santetti, G. S., Almeida, J. L., Bertolin, T. E., Gomez, M., Gutkoski, L. C. 2017. Properties of whole grain wheat flour and performance in bakery products as a function of particle size. Journal off Cereal Science 75, 269-277.

Darojat, D. 2010. Manfaat Penambahan Serat Pangan pada Produk Daging Olahan. Majalah Food Review 5:7, 52-53. 
De Garmo, E.P., Canade, J.R. dan Sullivan, W.G. 1984. Engineering Economy. MacMillan Publishing. New York: Seventh Edition.

Dignity, E. S. I., John, O. O., Awodi, Y. P., Aminat, Y. 2018. Production and evaluation of the physico-chemical and sensory properties of biscuit from wheat and cricket flours. Acta Scientific Nutritional Health 2:1, 3-7.

Diniyah N, A Puspitasari, A Nafi', A Subagio. 2016b. Characteristic of analog rice using hot extruder twin screw. J. Penelitian Pascapanen Pertanian 13 (1): 36-42.

Diniyah N, D Setiawati, WS Windrati, dan A Subagio. 2017. Karakterisasi mi mojang (mocafjagung) dengan perbedaan jenis dan konsentrasi bahan pengikat. J. Penelitian Pascapanen Pertanian 12(2): 98-107.

Diniyah N, L Firdaus, WS Windrati, A Nafi', A Prasetyo, dan A Subagio. 2016a. Indeks glikemik beras analog dari mocaf dengan substitusi jagung, ubi jalar ungu dan wortel. Warta IHP 33(2): 66-73.

Diniyah, N., Wahyu, F., dan Subagio, A. 2019. Karakteristik Tepung Premiks Berbahan Mocaf (Modified Cassava Flour) dan Maizena pada Pembuatan Cookies Green Tea. Jurnal Pangan dan Agroindustri 7:3, 25-36.

Diniyah, N., Windrati, W.S., Maryanto, Riady, S. 2015. Sifat fungsional tepung koro kratok hitam, merah dan putih (Phaseolus lunatus L.) dengan perlakuan lama perendaman. Jurnal Hasil Penelitian Industri 28:2, 70-77.

Diniyah, N., Windrati, W.S., Maryanto. 2013. Pengembangan Teknologi Pangan Berbasis Koro-koroan sebagai Pangan Alternatif Pensubtitusi Kedelai. Prosiding Seminar Nasional Pengembangan Sumber Daya Lokal untuk Mendorong Ketahanan Pangan dan Ekonomi. UPN Veteran, Jawa Timur.

Gayati, I. A. P. 2014. Pemanfaatan Tepung Kacang Koro Pedang (Canavalia Ensiformis [L.] Dc) dan Tepung Mocaf (Modified Cassava Flour) pada Cookies Ditinjau dari Sifat Fisiko Kimia dan Sensori. Skripsi. Fakultas Teknologi Pertanian. Universitas Katolik Soegijapranata. Semarang.

Iwe, M. O. 2002. Handbook of sensory method and analysis. Enugu, Nigeria: Rejoint Communication Service Ltd Uwani.

Kan, L., Nie, S., Hu, J., Wang, S., Cui, S. W., Li, Y., Xu, S., Wu, Y., Wang, J., Bai, Z., Xie, M. 2017. Nutrients, phytochemicals and antioxidant activities of 26 kidney bean cultivars. Food and Chemical Toxicology 108, 467-477.

Kiin-Kabari, D. B., Giami, S. Y. 2015. Physicochemical properties and in-vitro protein digestibility of non-wheat cookies prepared from plantain flour and Bambara groundnut protein concentrate. Journal of Food Research 4, 78-86.

Klunklin, W., Savage, G. 2018. Physical properties and sensory evaluation of wheat-purple rice biscuits enriched with green-lipped mussel powder (Perna canaliculus) and spices. Journal of Food Quality 1-9.

Lund, M. N., Ray, C. A. 2020. Control of maillard reactions in foods: strategies and chemical mechanisms. Journal of Agricultural and Food Chemistry 2017:65, 4537-4552.

Nafi', A., Diniyah, N. dan Hastuti, F. T. 2015. Karakteristik fisikokimia dan fungsional teknis tepung koro kratok (Phaseolus lunatus L.) termodifikasi yang diproduksi secara fermentasi spontan. Jurnal AGROINTEK 9:1, 24-32.

Nciri, N., Cho, N., Bergaoui, N., Mhamdi, F. E., Ammar, A. B., Trabelsi, N., Sami, Z., Fathi, G., Ben, M. A., Haj, S. F., Ben, A. F. 2015. Effect of qhite kidney beans (Phaseolus vulgaris $\mathrm{L}$ var. Beldia) on small intestine morphology and function in Wistar rats. Journal of Med. Food 18:12, 1387-1399.

Noorfarahzihah, M., Lee, J. S., Sharifudin, M. S., Mohd-Fadzelly, A B., Hasmadi, M. 2014. . Application of composite flour in development of food products. Application Food Research 21, 2061-2074.

Okpala, L., Egwu, P. N. 2015. Utilization of broken rice and cocoyam flour blends in the production of biscuits. Nigerian Food Journal 33:1, 8-11.

Onimawo, L.A. dan Akubor, P. I. 2005. Food Chemistry. Ambik Press Ltd. Benin City, Nigeria. 
Oracz, J., Nebesny, E. 2018. Effect of roasting parameters on the physicochemical characteristics of high-molecular-weight maillard reaction products isolated from cocoa beans of different Theobroma cacao L. groups. European Food Research and Technology 245, 111-128.

Ratnasari, D., Yunianta. 2015. Pengaruh tepung kacang hijau, tepung labu kuning, margarin terhadap fisikokimia dan organoleptik biscuit. Jurnal Pangan dan Agroindustri 3:4, 1652-1661.

Roland, W. S. U., Pouvreau, L., Curran, J., van de Velde, F., de Kok, P. M. T. 2017. Flavor aspects of impulse ingredients. Cereal Chemistry 94:1, 58-65.

Setyowati, W.T., Nisa, F.C. 2014. Formulasi biscuit tinggi serat (kajian proporsi bekatul jagung: tepung terigu dan penambahan baking powder). Jurnal Pangan dan Agroindustri 2:3, 224-231.

Subagio, A., Windrati, W. S., Witono, Y. dan Fahmi, F. 2008. Prosedur Operasi Standar (POS) : Produksi Mocal Berbasis Klaster. FTP UNEJ. Jember.

Subandoro, R. H., Basito, B.,. dan Atmaka, W. 2013. Pemanfaatan Tepung Millet Kuning dan Tepung Ubi Jalar Kuning Sebagai Substitusi Tepung Terigu dalam Pembuatan Cookies Terhadap Karakteristik Organoleptik dan Fisikokimia. Jurnal Teknosains Pangan 2:4, 68-74.

Tamanna, N., Mahmood, N. 2014. Food processing and maillard reaction products: effect on human health and nutrition. International Journal of Food Science 2015, 1-6.

Taub, I. A. and Singh, R. P. 1998. Food Storage Stability. CRC Press. New York.

Uthumporn, U., Woo, W.L., Tajul, A.Y., Fazilah, A. 2015. Physico-Chemical and Nutritional Evaluation of Cookies with Different Levels of Eggplant Flour Substitution. Cyta Journal of Food 13:2, 220-226.

Wei, Chao-Kun., Ni, Zhi-Jing., Thakur, K., Liao, Ai-Mei., Huang, Ji-Hong., Wei, Zhao-Jun. 2019. Color and flavor of flaxseed protein hydrolysates maillard reaction products: effect of cysteine, initial $\mathrm{pH}$, and thermal treatment. International Journal of Food Properties 22:1, 84-99.

Widya, R. 2011. Teknologi Pembuatan Makanan Dengan Menggunakan Tepung Mocaf Sebagai Subtitusi Tepung Terigu. STPP Medan.

Winarno, F. G. 1992. Pangan, Gizi, Teknologi, dan Konsumen. Gramedia Pustaka Utama, Jakarta.

Winarno, F.G. 2007. Kimia Pangan dan Gizi. Gramedia Pustaka Utama. Jakarta. 